\title{
The spread of COVID-19 Coronavirus in Romania: Approaches and Consequences on the Economy
}

\author{
Maria Ciurea
}

\author{
Department of Economics Sciences, University of Petrosani, Petrosani, 332070, Romania \\ Email: mariamacris2011@yahoo.com
}

\begin{abstract}
The spread of COVID-19 coronavirus in Romania affects and will affect economic and social activities for a long time to come. The extremely rapid evolution of such a pandemic has posed serious challenges to both the health system and the economic and social systems of the Member States of the European Union and around the world, affecting millions of people. These are the main reasons for the rapid management of economic and social problems and the promotion of solutions to support all sectors affected by the COVID-19 crisis. In this landscape of the global pandemic in which the lack of control and verified response tools imposed urgent measures, often affected by improvisation, the Romanian authorities tried to manage with their own resources and their own experience this unprecedented health crisis. The mentioned aspects constituted the objective of carrying out this scientific approach in the framework of which the influences and effects of the spread of COVID - 19 on the Romanian economy are debated.
\end{abstract}

Keywords: Coronavirus, COVID -19, România, pandemic, economic measures, economic effects

\section{INTRODUCTION}

The current period, strongly marked by the pandemic, in which unprecedented measures are required for the health system, it is necessary to intervene to prepare the economy for the management of the economic crisis, which will be impossible to avoid. In this respect, the elaboration of the set of measures is strongly affected by the fact that, at this moment, it is not possible to know the evolution of the epidemic. This is due to the fact that the fluctuating dynamics of data on the spread of the infections, complemented by the interventions of the authorities for the isolation of the population at home and also the drastic restriction of economic activities, cause frequent changes in the proposed set of measures [1]. For this period, prior to the ensuing global crisis, it is important to know with certainty the extent to which the population will be affected and the extent of the epidemic, both globally, in the European Union (EU) and nationally. Such an approach is opportune because, unlike previous crises, the current economic crisis will affect the economy of Romania's partner states, with a very large impact on the national economy [2]. Knowing with certainty the estimates of the evolution of the epidemic at these levels is extremely important, because without such assessments, it is not possible to estimate the impact on the macroeconomic framework, the development and implementation of real economic policy measures. Until the time of this paper, the statistics on the infection of the population with COVID - 19 from the beginning to the present is as follows [3]:

- total tests: 2,852,186:
- total confirmed cases COVID-19: 180,388;

- deaths: 5,872;

- patients who were declared cured:130,894;

- hospitalized patients at ATI: 749.

It is worth mentioning that in the last 14 days the average number of coronavirus infections has increased extremely, due to non-compliance with social distance measures, occasioned by the election campaign and local elections in late September and the beginning of the 2020/2021 school year.In addition to its significant social impact and human dimension, the coronavirus epidemic is a major economic shock to the EU, requiring an extremely strong economic coordination. The spread of the virus leads to disruption in global supply chains, financial market volatility, shocks to consumers demands and a negative impact on key sectors such as travel and tourism [4]. European stock markets fell by about $30 \%$ compared to mid-February, the sharpest monthly decline since the beginning of the 2008 financial crisis, and uncertainty about the outbreak in the coming weeks and months remains quite high. Due to the fact that, at the beginning of the pandemic with COVID-19, the initiatives taken in due time by the Romanian authorities compared to other countries, placed it in a favorable position regarding the number of people infected with coronavirus and the number of deaths reported to a million inhabitants, despite the initial shortages of stocks, reserves of protective materials and means of treatment in hospitals, state reserves, the lack of domestic producers of such materials and means, as well as the small number of specialized medical staff, from the cause of his emigration over the years [5]. In addition to these issues, Romania has been severely affected, mainly due to the suspension of many activities that involve large crowds of 
people with high exposure to disease, such as: various factories, restaurants, shops, hotels, cafes, shows, meetings sports, meant not only losses in the production of goods and services, but also the technical unemployment of more than one million people, representing $1 / 4$ of the total employed staff in the private sector, with income representing $75 \%$ of the salary [6]. All these aspects had a negative influence both for the supply and for the demand for products and services, with all the consequences derived from them.

\section{RESEARCH METHODOLOGY}

The COVID-19 pandemic caused not only human suffering, but also economic suffering, generating an unprecedented crisis. The current economic crisis is marked by a high degree of uncertainty about its duration and effects and bears no resemblance to previous crises from which it can be found, examples of solutions and ways to mitigate the magnitude of shocks and reduce their destructive effects. Such an approach to this phenomenon of 2020 completely unforeseen, can be achieved through qualitative research, resulting from the analysis of theoretical information taken from specialized studies, scientific conferences, research reports of the European Commission or other bodies, such as: the Ministry of Health, the National Bank of Romania, the National Institute of Statistics, relevant to this field, books or scientific articles published in various journals. Also, there were used as methods: induction and deduction, through which an exhaustive analysis of the influences and main effects that the spread of COVID-19 coronavirus has on the Romanian economy. The paper is a documentary type, considering its content and contribution, for which a series of stages were completed: planning, collecting information, analyzing them and the actual elaboration of the scientific approach.

\section{RESULTS AND DISCUSSIONS}

\subsection{The influence of the spread of COVID -19 on the Romanian economy}

The COVID - 19 coronavirus pandemic generated an immediate health crisis in the economies of all affected states, requiring measures to be taken that had the effect of closing various economic activities and restricting international trade. The current economic crisis is different from previous ones, due to the fact that it is selfprovoked by governments, in response to the health crisis and because it produces shocks on both supply and demand [7]. Although the solution seems simple at first glance, the uncertainty about the demand and the impact of social distancing measures for a large part of economic activities makes it difficult to find solutions, even if the vast majority of state economies have injected massive liquidity through various policies, which indicate a number of effects on the performance of household economies, investment funds and the financial system, which leads to exceeding the competencies derived from monetary policy objectives. Therefore, after this crisis, the economic recovery may be conditioned by many problems that may arise internationally.

After starting the pandemic, during the state of emergency, depending on the results of various analyzes performed on the economic situation in the context of the crisis generated by coronavirus COVID-19, a series of discussions took place at the level of the competent authorities: budgetary, in the field of social protection; the efficiency and effectiveness of the support measures dedicated to employees and the business environment, which were adopted by the Government for this period; the need for support for the recovery of the economy in the post-crisis period [8]. Therefore, in the institutional dialogue between the President of Romania and the representatives of the Government, for the evaluation of the measures regarding the management of the COVID19 coronavirus epidemic, the following topics were addressed:

$\checkmark$ the forms of intervention and the possibilities of financial support of the necessary measures identified by the Government;

$\checkmark$ state support for the affected sectors and for economic recovery;

$\checkmark$ increase of national production capacities and endowments with protective equipment and medical equipment;

$\checkmark$ proposals and solutions formulated by the business environment;

$\checkmark$ capitalizing on the positive experiences of Romania's main economic partners, European or international, in terms of economic measures adopted and implemented;

$\checkmark$ evaluating the effectiveness of support measures and the gradual resumption of economic activities;

$\checkmark$ the evolution of prices for different product categories (mainly sanitary / medical, agri-food, fuels, energy and utilities);

$\checkmark$ the situation of suspended employment contracts in the economy;

$\checkmark$ the economic and social measures required in the context of the extension for the state of emergency and the establishment of the state of alert;

$\checkmark$ macroeconomic situations and forecasts.

This pandemic has generated a shock to the economy as a whole, as well as to the labor market, affecting not only the production of goods and services, but also consumption and investment. Therefore, the outcome of the measures taken may affect supply and demand over a fairly long period, as such a crisis is more difficult to manage than a normal recession. In this context, there is the issue of "flattening" the epidemic curve or "flattening" the recession curve, which are unlikely to be achieved and for which more trade-offs will have to be made to get out of this crisis [9]. 
Regarding the measures taken by Romania to stop the coronavirus crisis COVID-19 and its other effects in the community, considered to be greater than the previous financial crisis, had as main purpose, both the protection of human life and health, and and maintaining economic activity at an appropriate level through budgetary and monetary measures. It should be mentioned that not only did the spread of COVID-19 coronavirus have economic effects that were difficult to assess in the costs of 2020 , but also the psychological pandemic, which led to disruption of human behavior, all with consequences for the functioning of capital and commodity and services, financial and monetary markets. In addition to the negative effects of this pandemic, a number of positive effects can be mentioned, such as: the acceleration of digitalized governance, the digitization of the whole social life and the acceleration of distance education [10]. The strategies that were adopted for each stage, to detect the nature of this economic and health shock, were important for the package of measures initiated and implemented by the government and the Central Bank National Bank of Romania (BNR). Therefore, all actions to control the spread of coronavirus, through various types of isolation, auto or disposable, have led to reduced production capacity, diminished links between employer and employees and market, between producers of goods/ providers of various services, such as: transport, tourism, public catering, education and consumers, all of which have a strong impact on production and revenue. In this context, the main responsibility of the authorities has been to mitigate the effects of the internal economic crisis, through measures taken that have stopped business restructuring at the limit of the possibility of resuming costs as low as possible, by protecting economic entities and labor tax incentives. Thus, an attempt was made to avoid the massive contraction of supply and demand, through the urgency of adopting normative acts so that the measures have a legal basis and functionality whose application was quite difficult to implement [11].

During all this period, the Romanian state tried to get involved with discernment in the payment of state aids, subsidies, state guarantees, tax deductions, deferrals of taxes and duties, support with public resources of technical unemployment, but also the normal payment of salaries, pensions and other social benefits. Under these conditions, the pressure on the budget has increased considerably, especially since this year began with a deficit beyond that provided by the Stability and Growth Pact (SGP), as Romania a member of the European Union (EU). In these conditions, the specialists in the field state that, at the level of 2020, the Gross Domestic Product (GDP) of Romania will contract by $5-7 \%$. Compared to other EU Member States, which have entered the pandemic with considerable budget surpluses, it indicates certain limits of the Government in providing fiscal facilities in conditions of limited resources, where the initiation of COVID-mitigation measures is different from other states [12].
In the current conditions of the spread of coronavirus, the reliable maintenance of the financial system is essential, and this aspect can be considered, to have been considered by the government and the NBR to counteract the uncertainties imposed by a future more difficult economic situation.

\subsection{The main economic effects of the coronavirus pandemic}

The spread of COVID -19 coronavirus has created sectors where demand has risen sharply as prices have risen and demand in other sectors has fallen. At the same time, a series of changes were observed in the offer beneficiaries, which will in turn generate structural changes in the economy. Consequently, the pursuit of coherent and coordinated monetary and fiscal policies that take into account the specificity of such an economic crisis, following that the measures taken will rebalance the purchasing power differentiated by sectors, increasing it where it tends to zero, i.e. in the case of closed or reduced economic activities, unemployment and reduce it where inflation is created and considerable supportive budgetary resources are consumed [13]. Also, this period of the pandemic can produce shocks on certain sectors of activity that will be transmitted to others through the complex channels of supply and demand. All this will lead to changes in prices and incomes in various sectors of the economy, so that part of the population can no longer meet the demand for available products, requiring in these cases a number of sector-specific intervention measures. As a result of the control established over the pandemic and the reduction of diseases, their effects on the economy begin to become visible. Thus, a certain way of recovery is required, not due to cyclical causes characteristic of the evolution of the market economy, but as a result of the restriction of economic activities so that the labor force is not exposed to disease [14].

All measures in the economic field adopted so far, are taken to reduce the social impact of the sharp decline in the volume of economic activity and social distancing that directly affects multiple areas of the economy. Unfortunately, the recent budget rectification was not likely to bring more optimism to the economic environment. Thus, the estimated contraction of $1.9 \%$ of the economy in 2020, compared to an economic growth of $4.1 \%$, which was the basis of the budget construction at the beginning of the year and the increase of the deficit to $6.7 \%$ of GDP, amplifies even more the worries and, at the same time, the precautions of the companies that see diminished their chances to receive another real support from the state [15]. To all these aspects, there is added the IMF forecast that anticipates a contraction of the Romanian economy of at least $5 \%$, compared to "only" $3 \%$ contraction of the global economy, thus anticipating an extremely reserved attitude of investors, both Romanians and especially those from outside the country. Such uncertainties, further amplify the sharp drop in 
demand generated by non-pharmaceutical interventions adopted in the emergency situation and amplify the psycho-behavioral impact on investors who, in such a period, become more concerned with conserving capital than to make a profit. At the same time, the lack of a plan to overcome the current economic crisis makes it impossible to develop a scientifically sound forecast of future economic developments, which are fundamentally determined by the government's non-formal actions. In the next period of time, we can expect the economic effects of COVID-19 coronavirus to extend to the balance sheet position of the population sector, both on the net wealth channel, due to the deterioration of real estate and capital market conditions, and from the perspective of diminishing incomes. Trends in the last 3 months in the evolution of economic activities have shown a relative stability of activity in industry, construction and services, a relative stability of the number of employees in industry, construction and services and a moderate increase in prices in construction and retail [16].

Regarding the labor market, the effects of COVID-19 coronavirus, both for medical and economic reasons, have generated a number of constraints, opportunities and costs. Thus, the following constraints were identified:

- measures to social distancing and isolate the employees have made economic entities vulnerable, so they have had to turn to the state for financial aid to help them continue their work after the restrictions on distancing are lifted

- the risk of infection at work, imposed measures of social distancing, with repercussions on economic activity, many companies opting for temporary suspension, reduction the activity or its temporary closure;

- the limitation of transports at national and international level and the closure of borders affected both the free movement of labor and the movement of goods with the exception of the transport of strictly necessary products: food, medicine, sanitary equipment, protective equipment, etc. necessary to combat the pandemic.

However, numerous opportunities have been reported on this market, including [17]:

$\checkmark$ rethinking national security strategies in order to stimulate business at national level to ensure the primary food and security needs of the population;

$\checkmark$ accelerating the digitalization of the economy, identifying an increase in online services, sales and promotion of products through online networks;

$\checkmark$ the increase in card payments leads to a decrease in tax evasion;

$\checkmark$ rethinking business strategies in order to better address national needs;

$\checkmark$ reshaping production lines to meet the specific needs of this period, highlights the first actions for the restructuring of the national economy, which after the end of this economic crisis, will be completely different as a result of economic and social changes;

$\checkmark$ flexibility of the workforce by including temporary work, tele-work, e-learning, which are easier to achieve in the field of professional and business services, financial and IT activities and much more difficult in the field of agriculture, fisheries, traditional occupations and industry;

$\checkmark$ supporting start-ups and innovation, in areas of national interest, such as: agriculture, food industry, tourism, IT;

$\checkmark$ curriculum adaptation in education is an opportunity for change, so that pupils and students are prepared to innovate and transform, digitization providing a safe chance for the fear of tomorrow and adaptation to an unpredictable environment.

Regarding the costs of the information available online, at this moment, we have identified values of 8,103.9 million lei for benefits following the suspension of activity, 6,042.4 million lei for balancing the social insurance budget and 16 billion lei for the IMMINVEST ROMANIA Support Program of small and medium enterprises for relaunching the activity, to which is added 200 million lei for the aid scheme for SMEs affected by COVID-19, repatriation costs, quarantine costs, parental costs and allowances [18].

In order to reduce the effects of COVID-19 coronavirus on the Romanian labor market, it is necessary to adopt a series of active measures to ensure:

- increasing the introduction of digital technologies in central and local public administration;

- increasing the employment rate and the number of jobs by: accelerating the public investment program in the large infrastructure, financial support of companies that provide sanitary materials and equipment, disinfectants, by granting large amounts or loans guaranteed by the state; supporting companies that provide warehousing and logistics for the sale of products to small Romanian farmers by granting large amounts or loans guaranteed by the state; stimulating restructuring the economy by providing tax aid to support businesses in areas that ensure the health and food security of the population (large amounts, working capital loans with state-guaranteed interest, easier access to European funds to support companies affected by the crisis);

- the introduction of information technologies in elearning education, taking into account the experience gained from the procedures developed by international bodies [19];

- the spread of COVID 19 coronavirus has made all employees at national level suddenly face significant changes, both in the family and in the professional activity, the most affected being workers with low wages and without access to social protection [20].

In the context of the increased demand for medicines and medical equipment, generated by the spread of COVID-19 coronavirus, the Romanian pharmaceutical industry is the only one that will register record business in 2020. Its growth rate will double this year, generating a figure of business of the production and distribution chain, which will reach approximately 68 billion lei, representing a historical maximum for the local market. It is also estimated that the local pharma industry, along with food 
retail, health and social assistance, IT\&C, agriculture that depends on weather conditions, energy and gas distributors, water and sanitation, will be less affected by this pandemic.

\section{CONCLUSIONS}

Depending on the concrete economic conditions of Romania, it is necessary and recommended that the government be inspired by the cautious methods of fiscal stimulation, in all advanced forms, of other states, but with tolerable applicability to the size and structure of the national economy. At the same time, the political authorities must refrain from overburdening the possible means to be used for the maintenance of economic activity and immediate recovery, but which must be correct and real, the credibility of the fiscal measures adopted being given by their good coordination at the national and European level.

The economic crisis generated by the spread of COVID 19 coronavirus is different from that of 2008 where the decision-making factor has the role of restarting economic activity throughout the national economy and contributing to the relaunch of economic growth, which is an extremely vital aspect. Public authorities are the ones who must encourage economic entities to start their work, and a clear and concise dialogue between entrepreneurs and local or central authorities is appropriate. Therefore, through the important measures that will be taken, such as increasing the guarantee ceiling, greater flexibility between funds, private investments, public investments can contribute to the restart and reconstruction of the economy in Romania, after this atypical economic crisis, following the reconstruction the national economy, not just its relaunch.

In order to stimulate economic growth for this period, economic measures should encourage consumption in the first phase, based on massive fiscal incentives injected by the government, to support the population and economic entities affected by the interruption of production activities, where a long-term program economic growth based on high investment spending could help restore growth levels at national level, as in the case of EU countries. Specialists in this field have strongly stated that the Romanian government is not able to implement a large package of fiscal incentives, such as tax cuts or spending increases, because it does not have the necessary fiscal space. As Romania's budget deficit is extremely large following the expansionist policies of the last 3 years, it is considered the country with the most unprepared economy among the European Community that will have to face such a crisis.

In Romania, in the context of a still high cost of labor production, related to qualification, firm actions will be needed to: achieve an efficient administrative system, investments in infrastructure, a high-performance research and development system, the transfer of results in production systems, a developed system of non-bank financing of companies (through investment funds or venture capital, etc.).

\section{REFERENCES}

[1] M.A. Kartseva, P.O. Kuznetsova, The economic consequences of the coronavirus pandemic: which groups will suffer more in terms of loss of employment and income? Population and Economics, 4(2) (2020) 26-33. DOI: https://doi.org /10.3897/popecon.4.e53194

[2] A. Iancu, Criza economică și sanitară COVID-19, schimbări în legislația economică a UE și unele efecte, în Studii economice, Academia română, iunie 2020

[3] Ministerul Sănătății, Comuncat de presă, Buletin Informativ 18.09.20, Available from: http://www.ms.ro/2020/10/18/buletin-informativ-1810-2020/

[4] M. Nicola, Z. Alsafi, C. Sohrabi, A. Kerwan, A. Al-Jabir, C. Iosifidis, M. Agha, R. Agha, The socio economic implications of the coronavirus pandemic (COVID-19): A review, International Journal of Surgery, (78) (2020) 185-193. DOI: https://doi.org/10.1016/j.ijsu.2020.04.018

[5] N. Pop, V. Ioan-Franc, A. M. Diamescu, Resetarea ordinii economice mondiale. Pandemia - noua față întunecată a globalizării, Academia Română, mai 2020, Available from: https://acad.ro/SARS-CoV2/doc/d03-Resetarea_ordinii_economice_mondiale.pdf [Accessed 28.09.2020].

[6] Banca națională a României, Raport asupra stabilității financiare iunie 2020, Anul V (XV), nr. 9 (19), Serie nouă

[7] V. Elenev, T. Landvoigt, S.Van Nieuwerburgh, Can the Covid Bailouts Save the Economy?, in Working Paper Series no. 27207, 2020, National Bureau of Economic Research, DOI: https://doi.org/10.3386/w27207

[8] L. L. Albu, C. I. Preda, Radu Lupu, C. E. Dobrotă, G. M. Călin, C. M. Boghicevici, Estimates of dynamics of the COVID19 pandemic and of its impacy on the economy, Romanian Journal of Economic Forecasting, XXIII (2) (2020) 5-17. Available from: http://www.ipe.ro/rjef/rjef2_20/rjef2_2020p5-17.pdf

[9]. D. A. Robalino, The COVID-19 Conundrum in the Developing World: Protecting Lives or Protecting Jobs?, in Discussion Paper Series, IZA DP no. 13136, 2020, http://ftp.iza.org/dp13136.pdf 
[11] M. Măcriş, Bazele economiei: manual universitar, Universitas, 2011

[12] M. Bălan, E. Pelinescu, C. Uzlău, B. Radu, Efectele pandemiei COVID-19 asupra pieței muncii: analize comparative și politici de răspuns, în Evaluări ale impactului macroeconomic al COVID-19, Coordonator: L. L. Albu, Academia Română, București, mai 2020, 17-25.

https://academiaromana.ro/SARS-CoV-2/doc/d08Impactul_macroeconomic_al_COVID-19.pdf

[13] INSSE, Evaluarea impactului COVID - 19 asupra mediului economic în lunile martie și aprilie 2020, Comunicat de presă, nr.104/15.04.2020

[14] Y. Qiu, X. Chen, W. Shi, Impacts of social and economic factors on the transmission of coronavirus disease 2019 (COVID-19) in China. Journal of Population Economics, (33) (2020), 1127-1172. DOI: https://doi.org/10.1007/s00148-020-00778-2

[15] Banca națională a României, Raport asupra inflației, august 2020, Anul XVI, nr. 61

[16] S.F. Karabag, An Unprecedented Global Crisis! The Global, Regional, National, Political, Economic and Commercial Impact of the Coronavirus Pandemic, Jurnal of Applied Economics and Business Research JAEBR, 10(1) (2020) 1-6. Available from: http://www.aebrjournal.org/uploads/6/6/2/2/6622240/j oaebrmarch2020_1_6.pdf [Accessed 9.10.2020]

[17] L. Chivu, G. Georgescu, Labor market vulnerabilities under the COVID-19 impact in Romania, MPRA Paper 101676, University Library of Munich, Germany

[18] M. Ciurea, The Digital Economy in Romania: Theoretical Approaches and the Current State of Development in the Context Imposed by the European Union, Advances in Economics, Business and Management Research (Atlantis Press), vol 105, Proceedings of the Ist International Scientific and Practical Conference on Digital Economy (ISCDE), 78 November, 2019, Chelyabinsk, Russia, pp.539-545. DOI: https://doi.org/10.2991/iscde-19.2019.104

[19] O. C. Popovici, Romania economy briefing: The impact of the coronavirus crisis on the economic activity, în China CEE Institute, 28(2) (2020)

[20] A. Butu, I. S. Brumă, L.Tanasă, S. Rodino, C. D. Vasiliu, S. Doboș, M. Butu, The Impact of COVID-19 Crisis upon the Consumer Buying Behavior of Fresh
Vegetables Directly from Local Producers. Case Study: The Quarantined Area of Suceava County, Romania, International Journal of Environmental Research and Public Health, 17(15) (2020) 5485. DOI: https://doi.org/10.3390/ijerph17155485 